\title{
Administration of ethanol extract of Bajakah tampala (Spatholobus littoralis Hassk) stem decreased reactive oxygen species, visceral fat and body weight of obese rats
}

\author{
Vany Novanty', \\ Wimpie Pangkahila ${ }^{1,2}$, \\ Ni Nyoman Ayu Dewi ${ }^{3}$
}

'Master Program in Biomedical Science, Concentration in Anti-Aging Medicine, Faculty of Medicine Udayana University, Bali, Indonesia ${ }^{2}$ Department of Andrology and Sexology, Faculty of Medicine Udayana University, Bali, Indonesia ${ }^{3}$ Department of Biochemistry, Faculty of Medicine Udayana University, Bali, Indonesia

\section{Cite this article:}

Novanty V, Pangkahila W \& Dewi NNA. Administration of ethanol extract of Bajakah tampala (Spatholobus littoralis Hassk) stem decreased reactive oxygen species, visceral fat and body weight of obese rats. Neurologico Spinale Medico Chirurgico. 202I.4(I):32-36. DOI:

I0.36444/nsmc.v4il.150

\section{Corresponding author:}

Vany Novanty

Master Program in Biomedical Science,

Concentration in Anti-Aging Medicine, Faculty of Medicine Udayana University, Bali, Indonesia novantyvany@gmail.com

\begin{abstract}
Background: Oxidative stress plays a role in the obesity mechanism, thus leads to premature aging. High antioxidant capacity in Bajakah tampala stem may effectively lessen oxidative stress and reduce fat mass and body weight accordingly. This study aimed to provide Bajakah tampala stem extract's effect in lowering ROS level, visceral fat weight, and overall weight of obese male Wistar rats.

Method: A true experimental design was conducted on male Wistar rats aged 2-3 months with obesity. Thirty-two obese rats were evenly divided into a placebo group and a group given Bajakah tampala stem extract, with 16 rats in each group. For 28 days, both groups were fed a high-fat diet. The subject body weights were weighed every week. ROS levels and visceral fat weight were evaluated after the intervention was done. Comparative analysis between groups was performed.
\end{abstract}

Results: The results showed mean levels of ROS $(56.2 \pm 7.4 \mathrm{U} / \mathrm{ml} v s .400 .9 \pm 50.7 \mathrm{U} / \mathrm{ml}$; p < $0.001)$, visceral fat weight $(2.6 \pm 0.2 \mathrm{~g} v s .3 .4 \pm 0.9 \mathrm{~g} ; \mathrm{p}<0.001)$, and the final body weight ( $241.5 \pm 2.8$ g vs. $261.5 \pm 13.8$ g; $p<0.001$ ) were significantly lower in the study group than the control group.

Conclusion: The study indicates Bajakah tampala stem extract administration effectively reduced ROS levels, visceral fat weight, and body weight in obese male Wistar rats.

Keywords: Bajakah tampala, Reactive Oxygen Species, Visceral Fat Weight, Body Weight, Obesity

\section{Introduction}

Excess fat that accumulates in the body is known to trigger inflammation in the body due to the release of bioactive substances, which will lead to the formation of excessive reactive oxygen species (ROS). Excessive ROS will cause oxidative stress and accelerating the aging process. ${ }^{1}$ Besides, obesity increases visceral fat in the abdomen and body weight due to high carbohydrate and fat diet composition. ${ }^{2}$ Visceral fat has more pro-inflammatory characteristics than subcutaneous fat. ${ }^{3}$ 
Oxidative stress increases in obese patients hence lead to diabetes, atherosclerosis, and degenerative diseases. In a study with obese mice, oxidative stress was found to occur mostly in adipose tissue but not in the liver, skeletal muscle, and aorta. This means that in obese, adipose tissue is the primary source of the formation of ROS. ${ }^{4}$ The morbidity and mortality rates for obese individuals are relatively high due to many complications. Therefore, appropriate, safe, and affordable prevention and management are needed for the community.

The obesity management approach refers to pharmacological and non-pharmacological therapy. Lifestyle changes by reducing calorie intake and increasing energy expenditure are also vital to losing weight. Medication such as sibutramine or orlistat can be done but is less preferred because of the rebound phenomenon side effect when the person stops taking it. Orlistat is also relatively expensive, so that alternative therapies using plants or herbs are gaining popularity. ${ }^{5}$

Currently, Bajakah tampala is a plant that has a great potential to be developed as a medicinal agent. This plant is widely used empirically by rural communities in Central Kalimantan for various diseases. Based on previous research, it is known that this Bajakah tampala's stem contains phenolic compounds, flavonoids, and tannins. ${ }^{6}$ Prashanth et al., (2020) stated that tannins (tannic acid) inhibit lipogenic signalling, suppress lipid metabolic pathways, and affect lipid profiles. ${ }^{7}$ Tannins in Bajakah tampala are expected to help weight loss as well as using pharmacological therapy.

Flavonoids are a group of phenolic compounds that have potential as antioxidants. ${ }^{8}$ In addition, Dzomba and Musekiwa (2014) showed that flavonoids could inhibit the lipase enzyme's action. The decreased activity of the lipase enzyme will inhibit the formation of adipocytes, thus inhibiting weight gain. ${ }^{9}$ Pancreatic lipases are known to perform $50-70 \%$ hydrolysis of total dietary fat. Decreased fat absorption through pancreatic lipase inhibition is very beneficial for obesity regulation. ${ }^{10}$ Phenol is a bioactive compound that can decrease free radicals harmful effects by inhibiting lipid peroxidation. ${ }^{11}$

It is known that obesity causes ROS formation causing oxidative stress and eventually degenerative diseases, the antioxidant capacity of Bajakah tampala administration is expected to decrease ROS levels in obesity and prevent degenerative diseases. Scientific research on Bajakah tampala stems only from its qualitative content and its effect on wound healing. Data on the potential effect of Bajakah tampala is yet limited. Therefore, the results of our study will contribute to the ongoing discussion on this issue.

\section{Methods \\ Ethical clearance}

The research was conducted at the Integrated Biomedical Laboratory, Faculty of Medicine, Udayana University, Denpasar, Bali. The research procedure was approved by the Animal Research Ethics Commission, Faculty of Veterinary Medicine, Udayana University (Number: 59/UN14.2.9/PT.01.04/2020).

\section{Bajakah tampala extraction}

The extract of Bajakah tampala stem (Spatholobus littoralis Hassk) in the study was obtained by extraction using $70 \%$ ethanol as a solvent. The residue was filtered and evaporated twice using a rotary evaporator to produce a brownish extract.

\section{In vivo experiment}

A post-test only control group study design was performed on a population of male Wistar rats aged 2-3 months. A total of 32 rats were required in the study according to the minimum sample calculation. The experimental animals were adapted for seven days before undergoing a high-fat diet for 35 days. The subjects were conditioned to be obese on this diet according to the criteria for Lee's Index $>0.3$. After 35 days, the rats were randomly divided into two groups: the control and study groups. The control group was given a placebo in the form of $1 \mathrm{ml}$ aquadest once a day and 20 grams of highfat diet ad libitum every day. The study group was given the extract of Bajakah tampala, at a dose of $350 \mathrm{mg} / \mathrm{kg}$ BW, and 20 grams of high-fat diet ad libitum every day. The procedures were lasted for 28 days, and the bodyweight of Wistar rats was weighed every week.

\section{Measurement of ROS}

ROS serum levels were examined using enzyme-linked immunosorbent assay (ELISA) procedure. Rat Reactive Oxygen Species ELISA Kit (Catalog No. MBS 38079 83, MyBiosource) were employed. Briefly, serum samples, reagents, and standards were prepared to be incubated for one hour and were added the chromogen solution A and B before incubated for another 15 minutes. Stop solution was added at the end of the procedure and Optical Density was read immediately at $450 \mathrm{~nm}$.

\section{Measurement of visceral fat and body weights}


intraperitoneal region, including omental and mesenteric fat, bordered with dorsal intestinal and the ventral kidney. The surgery started from the abdomen using bent scissors to separate the fat attached from the organ. Digital scale was used to weighed the fat and body weight. The body weights were measured every week.

\section{Statistical analysis}

Data analysis was performed using the SPSS 25 device (IBM, 2019). The comparative test was conducted to compare the results in the control group and the study group. An independent t-test was performed on data with normal distribution, while the Mann Whitney test was performed on data with the skewed distribution.

\section{Results}

The phytochemistry data of Bajakah tampala is presented in Table 1. The results showed that Bajakah tampala contained high antioxidant capacity with flavonoids and tannin were presiding antioxidant compound.

Table 1. Phytochemistry analysis result of Bajakah tampala antioxidant capacity

\begin{tabular}{cccccc}
\hline Sample Code & $\begin{array}{c}\text { Antioxidant } \\
(\mathbf{p p m})\end{array}$ & $\begin{array}{c}\text { Total } \\
\text { Capacity } \\
(\mathbf{m g} / \mathbf{L} \\
\text { GAEAC) }\end{array}$ & $\begin{array}{c}\text { Phenol } \\
(\mathbf{m g} / \mathbf{1 0 0} \\
\text { GAE) }\end{array}$ & $\begin{array}{c}\text { Flavonoids } \\
(\mathbf{m g} / \mathbf{1 0 0} \mathbf{g})\end{array}$ & $\begin{array}{c}\text { Tannin } \\
\text { Level } \\
(\mathbf{m g} / \mathbf{1 0 0} \\
\text { TAE) }\end{array}$ \\
\hline $\begin{array}{l}\text { Bajakah } \\
\text { tampala }\end{array}$ & 13.2535 & $63,141.06$ & $14,952.12$ & $79,739.7$ & $17,920.42$ \\
\hline
\end{tabular}

Table 2 displays the subject body weight measurement in both groups. The bodyweight was weighed before the study began and once every week for four weeks. The results showed that the mean bodyweights of the study group were relatively lower than the control group.

Table 2. Subjects mean bodyweights per week in the study and control group

\begin{tabular}{cccccc}
\hline \multirow{2}{*}{ Group } & \multicolumn{5}{c}{ Mean Bodyweight (g) } \\
\cline { 2 - 6 } & Week 0 & Week 1 & Week 2 & Week 3 & Week 4 \\
\hline Control & 246.9 & 249.6 & 252.8 & 256.8 & 261.5 \\
Study & 236.2 & 237.3 & 239.8 & 241.8 & 241.5 \\
\hline
\end{tabular}

The comparison analysis indicated that the mean of ROS levels $(\mathrm{U} / \mathrm{mL})$ in the study group was significantly lower than the control group ( $\mathrm{p}=0.000)$. The mean visceral fat (grams) and body weight in the study group were also markedly lower than the control group $(\mathrm{p}=$ 0.000). The comparison analysis results between the control group and the study group are shown in Table 3.

Table 3. Comparison of ros levels, visceral fat weight and bodyweight between study and control group

\begin{tabular}{lccc}
\hline \multicolumn{1}{c}{ Variable } & $\begin{array}{c}\text { Control Group(n=16) } \\
\text { X } \pm \text { SD }\end{array}$ & $\begin{array}{c}\text { Study Group(n=16) } \\
\mathbf{X} \pm \text { SD }\end{array}$ & $p$ \\
\hline ROS Levels (U/mL) & $400.9 \pm 50.7$ & $56.2 \pm 7.4$ & $0.000^{2}$ \\
Visceral Fat Weight $(\mathrm{g})$ & $3.4 \pm 0.9$ & $2.6 \pm 0.2$ & $0.000^{b}$ \\
Bodyweight (g) & $261.5 \pm 13.8$ & $241.5 \pm 2.8$ & $0.000^{b}$ \\
\hline analyzed using Mann Whitne; ${ }^{b}$ Analyzed using T-independent &
\end{tabular}

\section{Discussion}

Increased free fatty acid levels in visceral fat tissue on an obese individual will increase mitochondrial and peroxisomal oxidation causing free radicals, oxidative stress, and ultimately damaging cell structures. Cytokines production will increase, such as TNF- $\alpha$, resulting in higher ROS in tissues and lipid peroxidation. Excess adipose tissue is known to be a source of pro-inflammatory cytokines such as TNF- $\alpha$, interleukin (IL)-1 $\beta$, and IL-6. In physiological, as well as pathological conditions, adipokines also induce the formation of ROS. ${ }^{12}$

The mean ROS level analysis in the study group was significantly lower than the control group. These results indicate that the administration of Bajakah tampala ethanol extract for 28 days notably affect ROS synthesis to reduce ROS levels in obese male Wistar rats. The provision of antioxidants in the management of obesity is gaining in popularity because excess oxidative stress mechanism occurs in sufferers. The increasing prevalence of obesity globally triggers research on obesity to find more targeted and effective management. In recent years, antioxidants have been used widely to reduce excess ROS. The commonly used antioxidants are vitamins E and C, coenzyme Q, $\alpha$-lipoic acid, lycopene, flavonoids and polyphenols. Flavonoids and polyphenols are a high capacity antioxidants that widely available in foods and ingredients of natural origin. ${ }^{13,14}$ The Bajakah tampala stem extraction results showed potent antioxidant activity, with a high polyphenol composition including tannic acid and high flavonoids.

Flavonoids are known for their ability to interact directly with ROS. Previous studies have shown that flavonoids potential to reduce ROS levels due to ROS's scavenging mechanism and remove them from the body. ${ }^{12,15}$ Flavonoids can carry out secondary radical scavenging activities by transferring spare electrons to free radicals to have stable potential. ${ }^{15}$ Tannic acid and its related compounds inhibit hydrogen peroxide-induced oxidative DNA damage in human lymphocytes $\left(\mathrm{H}_{2} \mathrm{O}_{2}\right)$. Tannic acid serves as the primary defence against oxidative stress with its ability to scavenge free radicals or participate in reducing $\mathrm{H}_{2} \mathrm{O}_{2}$ catalyzed by GSH peroxidase, a selenium-dependent enzyme. Based on its redox properties, Tannic acid acts as a reducing 
agent, hydrogen donor, and decreases singlet oxygen so that it can reduce excess ROS. ${ }^{14}$

The mean visceral fat weight and body weight in the study group were significantly lower than the control group. These results indicate that administration of Bajakah tampala stem ethanol extract for 28 days significantly reduced visceral fat weight and body weight in obese male Wistar rats.

Visceral fat affects metabolic disorders by secreting inflammatory adipokines, such as IL-6, TNF- $\alpha$, chemoattractant protein-1 (MCP-1) macrophages, and resistin, which lead to insulin resistance and diabetes. ${ }^{16}$ In obesity, visceral fat is associated with local infiltration of various types of inflammatory cells. As in other noninfectious (sterile) inflammatory processes, the 'chronic' inflammatory infiltration of adipose tissue especially mononuclear cells is preceded by temporary infiltration of circulating neutrophils be found three days after initiation of a high-fat diet in laboratory rats. ${ }^{17}$ Furthermore, macrophages gradually become inflammatory cells that predominantly infiltrate adipose tissue. Macrophages secrete different cytokines such as IL-1b, IL-6, IL-8, TNF- $\alpha$ and MCP-1, which alter the expression and secretion patterns of adipokines and cytokines in adipose tissue. ${ }^{18,19}$ As a result, insulin sensitivity is impaired both locally and systemically. Therefore, obese individuals who are insulin resistant have a significantly higher macrophage infiltration in their adipose tissue than insulin-sensitive individuals. Macrophages are also higher in visceral fat tissue in the abdominal area, including the omentum, with two to four times the infiltration amount compared to other subcutaneous fat deposition. $^{20}$

Based on phytochemistry analysis of Bajakah tampala stem at the Integrated Service Laboratory, Faculty of Agricultural Technology, Udayana University on January 9th, 2020, Bajakah tampala stems contain flavonoids, polyphenol compounds including high tannins (Tannic acid). The combination of these ingredients has been widely researched to help weight loss and fat mass reduction. This is supported by a study conducted by Fan et al., (2013) who proved Tannic acid's effect in inhibiting the fatty acid synthesis and 3T3-L1 preadipocyte which plays a role in the formation of fat mass. Marranzano et al., (2018) conducted a cohort study on 2,044 adults, and the results showed that individuals with a high intake of flavonoids were less likely to be obese $(\mathrm{OR}=0.38$; 95\% CI: $0.21-0.66$ and $\mathrm{OR}=0.63$, 95\% CI: $0.39-$ 0.99), even after adjustment for confounding factors. The results of this study showed a relationship between high flavonoid intake and weight loss. ${ }^{21}$ Flavonoids have been reported to exert anti-obesity effects by activating or inhibiting the expression of genes responsible for regulating oxidative stress and anti-inflammatory defences. ${ }^{22}$ Among the inflammatory cytokines affected by flavonoid intake, TNF- $\alpha$, and IL-1b expression be reduced, resulting in increased antioxidant defences and substantial weight loss. ${ }^{23}$

Flavonoids inhibit the proliferation of preconfluent preadipocytes and increase energy expenditure. Flavonoids also activate the catabolic pathways that inhibit adipogenesis and lipogenesis through decreased lipoprotein lipase expression. ${ }^{13,24}$ Research conducted by Dzomba and Musekiwa (2014) showed that flavonoids could inhibit the lipase enzyme's action. ${ }^{9}$ Decreased lipase activation will inhibit adipocytes formation and expected to inhibit weight gain. ${ }^{25}$ Pancreatic lipase is the main enzyme associated with the absorption of triglycerides in the diet by hydrolysis of $50-70 \%$ of total food fat. As a lipase inhibitor, flavonoids combine with the active lipase part of the stomach and small intestine to suppress trypsin activity to reduce appetite because the sensation of fullness in the stomach lasts longer, inhibits catalytic activity, and reduces triglycerides. ${ }^{10} \mathrm{~A}$ review conducted by Song (2019) states that flavonoids in their role in reducing lipase can reduce the digestion and absorption of fat in food and the accumulation of adipose tissue and achieve the effect of controlling and treating obesity. ${ }^{26}$

\section{Conclusion}

In this study, the administration of ethanol extract of the Bajakah tampala stem decrease ROS levels, visceral fat weight, and body weight in obese male Wistar rats compared to controls. However, further clinical studies are needed to evaluate its side effects and toxicity. This research provides evidence on Bajakah tampala stem extract's potential to decrease levels of ROS, visceral fat weight, and body weight in obese rats.

\section{References}

1. Fernández-Sánchez A, Madrigal-Santillán E, Bautista M, et al. Inflammation, oxidative stress, and obesity. International journal of molecular sciences. 2011;12(5):3117-3132. DOI: 10.3390/ijms12053117

2. Lee JS, Kim K-J, Kim Y-H, et al. Codonopsis lanceolata extract prevents dietinduced obesity in C57BL/6 mice. Nutrients. 2014;6(11):4663-4677. DOI: 10.3390/nu6114663

3. Sugianti E, Afriansyah N. Faktor risiko obesitas sentral pada orang dewasa di DKI Jakarta: Analisis lanjut data Riskesdas 2007. Gizi Indonesia. 2009;32(2):105-116. DOI: 10.36457/gizindo.v32i2.73

4. Matsuda M, Shimomura I. Roles of adiponectin and oxidative stress in obesityassociated metabolic and cardiovascular diseases. Reviews In Endocrine And Metabolic Disorders. 2014;15(1):1-10. DOI: 10.1007/s11154-013-9271-7 
5. Egedigwe CA, Ejike CE, Ijeh II, et al. Anti-obesity potentials of aqueous and methanol extracts of Vernonia amygdalina Del. leaves in high-fat diet fed rats. African Journal of Traditional, Complementary and Alternative Medicines. 2016;13(2):86-93.

6. Saputera MMA, Ayuchecaria N. Uji efektivitas ekstrak etanolik batang Bajakah tampala (Spatholobus Littoralis Hassk.) terhadap waktu penyembuhan luka. Jurnal Ilmiah Ibnu Sina. 2018;3(2):318-327. DOI: 10.36387/jiis.v3i2.185

7. Nagesh PK, Chowdhury P, Hatami E, et al. Tannic acid inhibits lipid metabolism and induce ROS in prostate cancer cells. Scientific reports. 2020;10(1):980. DOI: 10.1038/s41598-020-57932-9

8. Rohyami Y. Penentuan kandungan flavonoid dari ekstrak metanol daging buah mahkota dewa (Phaleria macrocarpa Scheff Boerl). Jurnal Logika. 2008;5(1):116.

9. Dzomba P, Musekiwa C. Anti-obesity and antioxidant activity of dietary flavonoids from Dioscorea steriscus tubers. 2014;2(6):465-470. DOI: 10.12980/JCLM.2.201414B8

10. Ahn JH, Liu Q, Lee C, et al. A new pancreatic lipase inhibitor from Broussonetia kanzinoki. Bioorganic \& medicinal chemistry letters. 2012;22(8):2760-2763. DOI: 10.1016/j.bmcl.2012.02.088

11. Pourreza N. Phenolic compounds as potential antioxidant. Jundishapur Journal of Natural Pharmaceutical Products. 2013;8(4):149-150. DOI: 10.17795/jjnpp15380

12. Avsan Z, Kayali HA. Flavonoids showed anticancer effects on the ovarian cancer cells: Involvement of reactive oxygen species, apoptosis, cell cycle and invasion. Biomedicine \& pharmacotherapy. 2019;116:109004. DOI: 10.1016/j.biopha.2019.109004

13. Huang D, Jiang Y, Chen W, et al. Evaluation of hypoglycemic effects of polyphenols and extracts from Penthorum chinense. Journal of Ethnopharmacology. 2015;163:256-263. DOI: 10.1016/j.jep.2015.01.014

14. Larrañaga A, Isa ILM, Patil V, et al. Antioxidant functionalized polymer capsules to prevent oxidative stress. Acta biomaterialia. 2018;67:21-31. DOI: 10.1016/j.actobio.2017.12.014

15. Kim TY, Leem E, Lee JM, Kim SR. Control of reactive oxygen species for the prevention of Parkinson's disease: The possible application of flavonoids. Antioxidants. 2020;9(7): 583. DOI: 10.3390/antiox9070583

16. Tian YF, Chang WC, Loh $\mathrm{CH}$, et al. Leptin-mediated inflammatory signaling crucially links visceral fat inflammation to obesity-associated $\beta$-cell dysfunction. Life sciences. 2014;116(1): 51-58. DOI: 10.1016.j.lfs.2014.07.039
17. Elgazar-Carmon V, Rudich A, Hadad N, et al. Neutrophils transiently infiltrate intra-abdominal fat early in the course of high-fat feeding. Journal of lipid research. 2008;49(9): 1894-1903. DOI: 10.1194/jlr.M800132-JLR200

18. Fontana L, Eagon JC, Trujillo ME, et al. Visceral fat adipokine secretion is associated with systemic inflammation in obese humans. Diabetes. 2007;56(4):1010-1013. DOI: 10.2337/db06-1656

19. Item F, Konrad D. Visceral fat and metabolic inflammation: The portal theory revisited. Obesity Reviews. 2012;13(2):30-39. DOI: 10.1111/j.1467789X.2012.01035.x

20. Koster A, Stenholm S, Alley DE, et al. Body fat distribution and inflammation among obese older adults with and without metabolic syndrome. Obesity (Silver Spring). 2010;18(12):2354-2361. DOI: 10.1038/oby.2010.86

21. Marranzano M, Ray S, Godos J, et al. Association between dietary flavonoids intake and obesity in a cohort of adults living in the Mediterranean area. International journal of food sciences and nutrition. 2018;69(8):1020-1029. DOI: 10.1080/09637486.2018.1452900

22. Hossain MK, Dayem AA, Han J, et al. Molecular mechanisms of the anti-obesity and anti-diabetic properties of flavonoids. International journal of molecular sciences. 2016;17(4): 569. DOI: 10.3390/ijms17040569

23. Bjørklund G, Chirumbolo S. Role of oxidative stress and antioxidants in daily nutrition and human health. Nutrition. 2017;33:311-321. DOI: 10.1016/J.nut.2016.07.018

24. Rupasinghe HV, Sekhon-Loodu S, Mantso T, et al. Phytochemicals in regulating fatty acid $\beta$-oxidation: Potential underlying mechanisms and their involvement in obesity and weight loss. Pharmacology \& therapeutics. 2016;165:153-163. DOI: 10.1016/j.pharmthera.2016.06.005

25. Chater PI, Wilcox MD, Houghton D, et al. The role of seaweed bioactives in the control of digestion: Implications for obesity treatments. Food Funct. 2015;6(11):3420-3427. DOI: 10.1039/c5fo00293a

26. Song D, Cheng L, Zhang X, Wu Z, Zheng X. The modulatory effect and the mechanism of flavonoids on obesity. Journal of food biochemistry. 2019;43(8):e12954. DOI: 10.1111/jfbc.12954

27. Hseu YC, Chen XZ, Vudhya GY, et al. The skin-whitening effects of ectoine via the suppression of $\alpha$-MSH-stimulated melanogenesis and the activation of antioxidant Nrf2 pathways in UVA-irradiated keratinocytes. Antioxidants (Basel). 2020;9(1):63. DOI: 10.3390/antiox9010063 